\title{
A LITERATURE REVIEW ON INDIVIDUAL CREATIVITY SUPPORT SYSTEMS
}

\begin{abstract}
Individual creativity support systems have been developed to facilitate creative work. This article reviews the various design requirements and approaches proposed for supporting individual creative work, as well as relevant creativity theories. Current creativity support systems use many approaches in supporting the collection of relevant information and the creation of ideas or artifacts. However, the designs are typically based on just a few creativity theories. Based on various creativity theories, we propose a new integrated framework for individual creativity support systems. This framework enumerates aspects, components, and features of creativity support systems.
\end{abstract}

Keywords: Creativity support systems, innovation, design, creativity theory

\section{Introduction}

Information systems often focus on the storing and retrieval of information, but there is also a role for specialized information systems that contribute to innovation processes in companies - product design, idea generation, research and development, etc. These systems are called creativity support systems. Creativity support systems aim at enhancing creativity by stimulating and documenting creative processes (Massetti, 1996; Wierenga \& van Bruggen, 1998). Creativity is defined as the generation of novel and useful ideas or products (Amabile, 1996), and so the range of such systems is wide. For example, Group Support System ThinkTank is used for collaborative idea generation in large organizations (Voigt, Niehaves, \& Becker, 2012). In addition to supporting group idea generation (Dennis, Valacich, Connolly, \& Wynne, 1996; Klein \& Dologite, 2000; Wang, Cosley, \& Fussell, 2010), creativity support systems have been design for computer-aided design (Sugimoto, Hori, \& Ohsuga, 1994; Chaudhuri \& Koltun, 2010), knowledge management (Lin \& Hwang, 2014), musical composition (Eaglestone, Ford, Brown, \& Moore, 2007), and culinary art (Mueller, Debortoli, \& Seidel, 2013). 
Furthermore, creativity support can be included in decision support systems (Elam \& Mead, 1990; Forgionne \& Newman, 2007) and enterprise mobile applications (Chung, Lee \& Choi, 2014). Obviously creativity support systems are useful in various domains. Although different creative domains have their own idiosyncrasies, researchers believe that some principles and major components are common in creativity support systems (Hewett, 2005; Shneiderman, 2002).

Creativity support systems are important not only because they offer help to practitioners, but also because they are where theories of creativity become manifest. That is, ideas about divergent and convergent thinking can seem very abstract, but they become concrete when instantiated in a system that takes a practitioner through the stages of a design process. Because of this, creativity support systems may provide insights into creativity in general, and, more specifically, in how the theories and practices of creativity can be combined. In this vein, we review relevant empirical and theoretical studies to better understand creativity support systems.

Creativity support systems can be classified into group creativity support systems and individual creativity support systems, supporting groups and individuals, respectively (Mueller-Wienbergen, Mueller, Seidel, \& Becker, 2011). A recent review by Gabriel et al. (2016) is focused on empirical studies in group creativity support systems. This paper will instead focus on individual creativity support systems for two reasons. First, individual creativity is indispensable in group creative work. Therefore, understanding the principles for supporting individual creativity is an important step in going towards the group level. Second, despite the popularity of teamwork, some decisions and creative work are still done by individuals. Hence, individual creativity support systems are still quite relevant for the industry (Malaga, 2000).

Creativity support systems, like other information systems, are most effective when they instantiate underlying theories (Hevner, March, Park \& Ram, 2004; Voigt et al., 2012). The literature on individual creativity support systems has drawn theories about design, human computer interaction, information systems, and creativity (Avital \& Te'eni, 2009; Voigt et al., 2012; Yamamoto \& Nakakoji, 
2005). However, as reviewed below, the principles proposed are typically based on one or two creativity theories while there are many creativity theories worth consulting. Thus, we will present a review of relevant creativity theories and integrate the theories into a framework for individual creativity support systems. This article aims to be useful for those building systems to support creative processes, as well as those building theories of creativity and innovation.

\section{Method}

This article reviews research on single-user creativity support systems and tools, along with relevant theories on individual creativity. For the former, we systematically searched two research databases: Scopus and Web of Science. Search phrases include "creativity support systems" and "creativity support tools". Additional studies were identified in forward and backward citations. We focus on journal articles and highly cited conference articles. All the articles were screened to find those that focus on the support of individual work. In these articles, we also identified relevant creativity theories. Additional relevant theories on individual creativity were identified by a comprehensive search on creativity theory in Scopus and Web of Science, as well as from textbooks on creativity (Davis, 2004; Puccio, Murdock, \& Mance, 2007; Runco, 2007). Specifically, cognitive and motivational perspectives of creativity were selected for review because they often generate insights for practical approaches to improving creativity (Plucker \& Runco, 1999). In contrast, other theoretical approaches to creativity, such as organizational, clinical, and psychedelic perspectives are not discussed because they are less likely to have implications for individual creativity support systems.

\section{Individual Creativity Support Systems}

\subsection{Overall Frameworks}

There are various overall frameworks on how information systems can help with creative work. According to Lubart (2005), there are four approaches: "computers may facilitate (a) the management of creative work, (b) communication between individuals collaborating on creative projects, (c) the use of creativity enhancement techniques, (d) the creative act through integrated human-computer cooperation 
during idea production." In reality, these approaches are not mutually exclusive: creativity support systems can use multiple approaches. However, the third approach, using creativity enhancement techniques, is dominant in individual creativity support systems (Malaga, 2000; Mueller-Wienbergen et al., 2011). Somewhat similarly, it is argued that there are three levels of computer support for creative work: the secretarial level when computer is used as an electronic blackboard, the framework-paradigm level when computer provides frameworks and examples to guide users, and the generative level when computer can generate ideas (Chen, 1999; Young, 1987).

An information processing model of creativity (IPC model) was constructed to guide computational creativity (Schmid, 1996). The model has three key components: memory, operators and control. Memory refers to the knowledge relevant to the creative task. This knowledge includes internal and external knowledge (such as using experiments or external stimuli). Operator refers to one form of information processing, such as problem recognition, search for knowledge, and restructuring knowledge. Control refers to the monitoring and control of the creative process through selecting actions, applying operators, evaluating intermediate results and learning. While the IPC model is not implemented, the theoretical analysis leads to some potential research topics such as integrating heuristic methods and learning into information systems and the integration of many operators.

In a recent study, three latent variables for supporting creativity were extracted from a review of different design theories: playfulness, comprehension and specialization (Voigt, Niehaves, \& Becker, 2012). Playfulness refers to the ability of creativity support systems to encourage trialability (in essence, testability) and to enable users to create final results iteratively. Comprehension is the ability of these systems to facilitate a quick and clear understanding of the artifacts used for ideation. Specialization is the property of a system that enables task specific support and its re-use through selection and arrangement. While it is commonly recognized that creative work uses both divergent and convergent thinking (Brophy, 1998), these three properties mainly support divergent thinking and are less related to 
convergent thinking. In addition, this framework is constituted from a variety of design theories of creativity support systems with few explicit connections to underlying creativity theories.

Avital and Te'eni (2009) proposed a set of design principles for information systems to support generative capacity, the ability to produce something ingenious. The authors argued that such systems should be evocative through features such as visualization and abstraction, be adaptive through customization and automation, and be open-ended through peep-production and rejuvenation. The evocative principle is based on the notion that juxtaposing diverse frames that are less commonly associated may lead to creative insights (Sternberg, 1988). However, it is unclear what other creativity theories are consulted.

Grounded on one theory on ideation, the search for ideas in associative memory theory (Nijstad \& Stroebe, 2006), Knoll and Horton (2011) identified three mental principles for supporting idea generation: jumping, dumping and pumping. Jumping means moving to a different location in the associative network in mind. Dumping means challenging assumptions. Pumping means focusing on specific concepts related to the creative task. All three activities can be achieved by using some external stimuli. This framework provides new insights for supporting ideation through the exploration of an associative network of knowledge.

Shneiderman (2002) suggests that creativity support systems should support four activities within a creative process:

Collect: Learn from previous work stored in libraries, the Web, and other sources.

Relate: Consult with peers and mentors at early, middle, and late stages.

Create: Explore, compose, and evaluate possible solutions.

Donate: Disseminate the results and contribute to libraries, the Web, and other sources. (Shneiderman, 2002:116-117)

Shneiderman and colleagues (2006) also proposed a set of user interface design principles, such as support exploration and iteration, support many paths and many styles, and design the tool such that you would want to use yourself etc. While both frameworks seem reasonable, it is less clear what creativity theories were consulted in developing them. 
Cherry and Latulipe (2014) proposed a creativity support index to cover six dimensions: Exploration, Expressiveness, Immersion, Enjoyment, Results Worth Effort, and Collaboration. Immersion here means the degree to which a user is absorbed in the creative activity. Results Worth Effort means the degree to which a user believes that the creative outcome is worth the effort put into it. The six dimensions of the index not only enable a more comprehensive evaluation, but also suggest different aspects of creativity support systems for designers to consider. However, it is less clear how these six dimensions are related to creativity theories.

\subsection{Specific Approaches Supporting Creativity}

\subsubsection{Overview of the Stages Supported}

Our search of the literature identified 48 different systems or approaches supporting individual creative work (listed in the Appendix). Within the 48 empirical studies, there are 25 approaches that are domain general. For example, these methods may support brainstorming or case-based reasoning that can be applied to various creative domains. There are 9 approaches focused on engineering design and innovation, 7 approaches supporting product design, 3 methods in linguistic creativity, 2 methods in musical creativity and 2 approaches for graphic design.

Since a creative process is commonly assumed to have different stages or phases (Amabile, 1996; Gabriel et al., 2016; Wallas, 1926), it is useful to identify the stages that each approach supports. The commonly mentioned stages include problem finding (Amabile, 1996; Gabriel et al., 2016; Treffinger, 1995), information finding (Amabile, 1996; Shneiderman, 2002; Treffinger, 1995), idea finding (Amabile, 1996; Gabriel et al., 2016; Treffinger, 1995), and solution finding (Althuizen \& Reichel, 2016; Marakas \& Elam, 1997; Treffinger, 1995). Solution finding is different from idea finding in that complete solutions are produced by refining selected ideas and working out the details (Althuizen \& Reichel, 2016). Table 1 shows the statistics about the stages being supported in the 48 approaches. Most individual creativity support systems support one or two stages. Idea finding is the most commonly supported stage while problem finding is the least commonly supported. 


\subsubsection{Approaches Supporting Problem Finding}

For problem finding, there are only 7 studies that mention its support. Some of these methods simply provide a process guide that includes problem identification (Althuizen \& Reichel, 2016; Elam \& Mead, 1990; Makaras \& Elam, 1997). Other methods include identifying and connecting problem elements (Forgionne \& Newman, 2007; MacCrimmon \& Wagner, 1994), visualizing the concept space of design (Hori, 1997), and guiding the problem definition process such as maximizing and minimizing the problem (Liu et al., 2011). It is clear that there is a lack of sophisticated approaches to supporting problem finding.

Table 1. Stages of the Creative Process Covered by the Individual Creativity Support Systems.

\begin{tabular}{|c|c|c|c|}
\hline $\begin{array}{l}\text { Number of Stages } \\
\text { Covered }\end{array}$ & Stages & $\begin{array}{l}\text { Number of Systems or } \\
\text { Approaches }\end{array}$ & Proportion (\%) \\
\hline \multirow{2}{*}{$\begin{array}{l}1 \\
(43.8 \%)\end{array}$} & Idea Finding & 17 & 35.4 \\
\hline & Information Finding & 4 & 8.3 \\
\hline \multirow[t]{2}{*}{$\begin{array}{l}2 \\
(33.3 \%)\end{array}$} & $\begin{array}{l}\text { Idea and Information } \\
\text { Finding }\end{array}$ & 6 & 12.5 \\
\hline & Idea and Solution Finding & 10 & 20.8 \\
\hline \multirow[t]{3}{*}{$\begin{array}{l}3 \\
(14.6 \%)\end{array}$} & $\begin{array}{l}\text { Problem, Information and } \\
\text { Idea Finding }\end{array}$ & 1 & 2.1 \\
\hline & $\begin{array}{l}\text { Problem, Idea and } \\
\text { Solution Finding }\end{array}$ & 2 & 4.2 \\
\hline & $\begin{array}{l}\text { Information, Idea and } \\
\text { Solution Finding }\end{array}$ & 4 & 8.3 \\
\hline $\begin{array}{l}4 \\
(8.3 \%)\end{array}$ & All the Stages & 4 & 8.3 \\
\hline
\end{tabular}

\subsubsection{Approaches Supporting Information Finding}

There are 19 systems or approaches that support information finding in creative work. Creativity support systems have been proposed that provide specific knowledge about the task (Kletke et al., 2001), access digital libraries and the Web (Shneiderman, 2002) and support the search of relevant information (Greene, 2002; Herring, Jones, \& Bailey, 2009; Hewett, 2005). Mueller-Wienbergen et al. (2011) stress the importance of knowledge in creative work and propose that creativity support systems should support knowledge acquisition and therefore have the following functions:

Organize available knowledge hierarchically 


\section{Provide diverse perspectives on existing knowledge}

\section{Enable dynamic filtering of the knowledge base (Mueller-Wienbergen et al., 2011)}

In addition to these theoretical arguments, there are also empirical studies focused on the information finding. Some researchers use a process guide that contains the information finding step (Elam \& Mead, 1990; Marakas \& Elam, 1997). A system called combinFormation supports information collection, integration, and visualization and is shown to improve idea generation (Koh, Kerne, \& Hill, 2007). Similarly, providing a knowledge base or case-based reasoning system (Althizen \& Wierenga, 2014; Cheung et al., 2008; Forgionne \& Newman, 2007; Liu et al., 2011), visualizing information or the concept space (Brade, Heseler, \& Groh, 2011; Fentem, Dumas, \& McDonnell, 1998; Hori, 1997; Sugimoto, Hori, \& Ohsuga, 1996), using data synthesis for uncovering important information (Wang \& Ohsawa, 2013), and organizing research notes (Aihara \& Hori, 1998) have all been used to support information finding. Jenkin and colleagues (2013) developed a system to identify novel information related to a topic. They iteratively use original keywords and new keywords extracted from previous search results to identify information that is both relevant and novel. The novel information can then be used to facilitate innovation.

\subsubsection{Approaches Supporting Idea Finding}

There are 42 systems or approaches that support idea finding in creative work. Information systems have been proposed that supply different types of stimuli (MacCrimmon \& Wagner, 1994; Malaga, 2000; Mueller-Wienbergen et al., 2011; Viriyayudhakorn, Kunifuji, \& Ogawa, 2011), that provide previous successful cases (Althuizen \& Wierenga, 2014), that support the connection of different elements in a problem (MacCrimmon \& Wagner, 1994), that catalyze thinking by free associations (Shneiderman, 2002), that support iteration and experimentation (Greene, 2002), that provide affective or achievement priming (Lewis, Dontcheva, \& Gerber, 2011; Dennis, Minas, \& Bhabwatwar, 2013), that support metaphorical and analogical thinking (Chen, 1996; Veale, 2006; Young, 1987), and that facilitate the use of idea generation techniques (Garfield et al., 2001). 
There are many studies focused on idea finding in specific domains: most notably engineering design and innovation (e.g., Hori, 1997; Gero, 2000; Gomes et al., 2006; McCaffrey \& Spector, 2011; Sedivy \& Johnson, 2000), and product design (e.g., Chakrabarti et al., 2005; Gerber \& Martin, 2012). Computational aids for engineering design have attracted much attention. Hori (1997) built a system that visualizes the concept space of design through showing design requirements and design parameters. This visualization of concept space facilitates the generation of design strategies by users. Using analogies to support software design was studied by Gomes et al. (2006). A case library that stores previous software designs was available to provide analogy candidates. WordNet was used to facilitate semantics-based retrieval of analogy while structural properties of design diagram were also used to retrieve analogies. The comparison of two analogy retrieval strategies showed that structure-based retrieval led to more novel diagrams. Gero (1996) argues that creative design can be broken down into three elements: function, behavior and structure. A genetic algorithm framework has been developed where these elements undergo combination and mutation to maximize performance (Gero, 1996). In related work, it has been observed that common processes in creative design, e.g. combination, transformation and analogy, may be supported by computational tools (Gero, 2000). Sedivy and Johnson (2000) developed a tool for sketching. Based on theoretical analysis and observation of sketching, they identified key requirements for such an iterative process, including access to functionality quickly, support for layers, allowing easy manipulation on drawings, maximizing space for drawing etc. The tool met these requirements, facilitated the iteration and increased productivity.

A new approach has been developed for finding ideas in engineering problem solving when physical features are important. This approach is based on the notion that innovation usually results from noticing and using non-obvious features of some problem elements (McCaffrey \& Spector, 2011). Building on semantic networks of physical features, software has been developed to guide users to potentially obscure-but-useful features for problem solving. These useful features are typically moderately distant from the problem or concept in the semantic networks because a feature that is too 
common or too remotely related is less likely to be effective in stimulating ideas. This approach provides novel ways to think about physical problems. However, the semantic network of physical features needs to be manually constructed, which is a demanding task.

Some methods in supporting product design have been developed, such as using product design templates (Liu et al., 2011), systematic use of biomimetic approaches (Chakrabarti et al., 2005), searching for inspiring images (Setchi \& Bouchard, 2010), and using 3D-CAD (Chang et al., 2016). Gerber and Martin (2012) offered design principles for creativity support in web-based product customization. The principles include providing an optimal challenge, autonomy, having a community and resources, facilitating goal setting, as well as supporting positive affect, etc. Clearly these principles are based on motivation theories. These design principles appear generic and might be widely applicable in motivating creative work with creativity support systems.

Idea finding in other domains is usually supported with highly domain specific methods. Idea finding in music, or music composition, can be supported with software that supports the generation of chord or accompaniment by combining music knowledge, human input and statistical learning (Chuan \& Chew, 2007; Riley, Alm \& Newell, 2009).

Sedivy and Johnson (2000) built a system called Speak'n'Sketch to assist creative sketching. The system allows voice control of the software so that hand drawing is not interrupted. The system also facilitates drawing in layers and easy manipulation of graphics. Hung and Choy (2013) proposed an approach supporting graphic design, called conceptual recombination, to take in intermediate creative work and generate creative designs as continuations. Using domain knowledge, the approach first tries to understand the features and structures of the input, then the input features and structures are used to predict output features and structures, which combine into a final product. A computational model was developed to operationalize this approach. The utility of this approach was illustrated in a 3D design task.

Linguistic creativity can be supported with computational techniques in analogy and conceptual blending (Hedblom, Kutz, \& Neuhaus, 2016; Veale, 2006; Young, 1987). For example, Veale (2006) 
used WordNet and its category structures to computationally retrieve analogies. Hedblom and colleagues (2016) proposed a computational approach to blend concepts based on the image schemas behind the concepts. Since creating new analogies or concepts can be potentially useful for domains outside of linguistics, these approaches in idea finding may be applicable to other domains.

\subsubsection{Approaches Supporting Solution Finding}

There are 20 systems or approaches that support solution finding in creative work. Solution finding is often supported by a process guide that includes a separate stage where ideas are selected, refined, enriched and integrated into solutions (Elam \& Mead, 1990; Forgionne \& Newman, 2007; Liu et al., 2011; Marakas \& Elam, 1997). Another common approach is to show relevant and complete solutions to inspire creative work (Althuizen \& Wierenga, 2014; Chen, 1999; Shai, Reich, \& Rubin, 2009; Vattam et al., 2010; Zanni-Merk, Cavallucci, \& Rousselot, 2009). Lastly, domain specific methods have been used to support solution finding, including the use of 3D-CAD in product design (Chang et al., 2016) and providing computer-based simulations to support the selection, testing and refinement of final solutions (Tennyson \& Breuer, 2002).

\subsection{Summary}

The growing computational power and technical capabilities have enabled many approaches to support creative work, including general problem solving, engineering and product design, visual arts, musical and linguistic creativity. However, the empirical studies tend to consult limited number of creativity theories while ignoring other creativity theories. For example, while creativity theories often suggest that there are different stages in a creative process, a single-user creativity support system typically supports only one or two stages. The empirical approaches tend to focus on idea finding and ignore problem finding. To better understand the future of creativity support systems, the authors argue that a thorough understanding of various creativity theories is beneficial. Therefore, the next section reviews various relevant creativity theories.

\section{Relevant Theories of Creativity}


Theories and models for creativity are quite diverse. We intend to review theories that are domain general so that the implications for creativity support systems are widely applicable. Here only those theories that are directly relevant to individual creativity support systems are discussed. We include all the creativity theories mentioned in the literature of individual creativity support systems. Additional theories are included if they are taking cognitive or motivational perspectives of creativity. These relevant theories and models are classified into four types (summarized in Table 2).

\subsection{Factorial Theories}

Taking a factorial approach, the componential theory of creativity (Amabile, 1983) states that the three components of creativity are domain-relevant skills, creativity-relevant skills and task motivation, especially intrinsic motivation. The theory suggests three potential approaches to promote creativity: to increase knowledge and skills in certain domains, to provide training in creative thinking and facilitate the thinking process, and to motivate people on certain tasks. Explicit-implicit interaction (EII) theory emphasizes that creative problem solving results from the integration of results of both explicit and implicit processing of knowledge (Helie \& Sun, 2010). Explicit processing is usually rule based while implicit processing is typically associative. Decision support systems often focus on explicit processes such as modeling and data analysis (Sinha \& May, 1996) and do not support implicit processes. EII theory suggests that creativity support systems should support both rule-based processes and associative processes. The 4-Ps theory of creativity (Rhodes, 1961) argues that the four aspects of creativity are creative person, creative process, creative product and creative press (environment). This theory suggests that the design of creativity support system should consider all these four aspects. According to the systems model of creativity (Csikszentmihalyi, 2009), creativity emerges from a system composed of three elements: a domain with symbolic rules, a person who brings novelty into the domain, and a field of experts who recognize and validate the creative outcome. This model suggests that a creativity support system should support the use of symbolic rules in a domain, as well as help a user meet the expectations of experts. 
The dual pathway to creativity theory (Nijstad et al., 2010) argues that to generate novel ideas, people need to either explore a specific category in more depth (the persistence pathway) or search for ideas in a broader range of categories (the flexibility pathway). This theory suggests that a creativity support system can be effective in promoting the persistence pathway by guiding people to think in a category deeply. This may be achieved by providing many stimuli in one category. Alternatively, a creativity support system can be effective in promoting the flexibility pathway through stimulating exploration in diverse categories. This can be achieved by providing stimuli in various categories.

Table 2. Creativity Theories Relevant to Individual Creativity Support Systems.

\begin{tabular}{|l|l|l|}
\hline Types of Theories & Description of the Type & Examples \\
\hline Factorial Theory & $\begin{array}{l}\text { Creativity is composed of } \\
\text { different factors or aspects }\end{array}$ & $\begin{array}{l}\text { Componential theory of creativity (Amabile, } \\
\text { 1983), 4-Ps theory (Rhodes, 1961), Systems } \\
\text { Model of Creativity (Csikszentmihalyi, 2009), } \\
\text { Explicit-implicit interaction theory (Helie \& } \\
\text { Sun, 2010), Dual pathway to creativity theory } \\
\text { (Nijstad et al., 2010) }\end{array}$ \\
\hline Associative Theory & $\begin{array}{l}\text { Creativity is based on } \\
\text { associations. }\end{array}$ & $\begin{array}{l}\text { Associative theory of creativity (Mednick, } \\
\text { 1962), Bisociation theory (Koestler, 1964) }\end{array}$ \\
\hline Stage Theory & $\begin{array}{l}\text { The creative process consists } \\
\text { of certain stages. }\end{array}$ & $\begin{array}{l}\text { Four-stage model (Wallas, 1926), Osborn- } \\
\text { Parnes creative problem solving process } \\
\text { (Treffinger, 1995), Geneplore model (Finke, } \\
\text { Ward, \& Smith, 1992), Search for ideas in } \\
\text { associative memory model (Nijstad \& Stroebe, } \\
\text { 2006), Blind variation and selective retention } \\
\text { (BVSR) theory (Campbell, 1960) }\end{array}$ \\
& $\begin{array}{l}\text { Three views on creativity (Shneiderman, 2002), } \\
\text { Three ways of creativity (Boden, 2004), } \\
\text { Model of individual creativity (Seo, Chae \& } \\
\text { Lee, 2014) }\end{array}$ \\
\hline $\begin{array}{l}\text { Miscellaneous } \\
\text { Theories }\end{array}$ & $\begin{array}{l}\text { Other types of creativity } \\
\text { theories }\end{array}$ &
\end{tabular}

\subsection{Associative Theories}

The associative theory of creativity argues that creativity is the process of combining mental elements and associative thinking can connect mental elements (Mednick, 1962). The possibility of getting a creative response is positively related to the distance between associative elements. The theory further argues that people with flat associative hierarchies, i.e., people who have weaker associations from an initial stimulus to a large set of elements, tend to be more creative. Similarly, Koestler (1964) argues 
that creativity results from "bisociation", an unexpected synthesis of elements from two thoughts into a new idea. In other words, creativity results from the association of two seemingly incompatible frames of reference within a new context. Dual coding theory (Paivio \& Lambert, 1981) assumes that cognition is served by two separate symbolic systems: verbal and nonverbal. The two systems can function independently. However, the two systems are connected in that elements in one system can activate those in the other. Therefore, an association across systems can occur. Even though dual coding theory is not specifically focused on creativity, it has the implication that creativity can result from associations in or across verbal and nonverbal systems.

\subsection{Stage Theories}

Many creativity theories describe the cognitive process of creative thinking as a series of stages or steps. One such theory is called search for ideas in associative memory (Nijstad \& Stroebe, 2006). The model assumes two memory systems: long-term memory and working memory. Long term memory stores a richly interconnected knowledge network with many categories and associations. The network is composed of images, i.e., knowledge structures with a central concept and its features or associations. Images are associated to each other and may overlap. Working memory, which has limited capacity, offers temporary storage of images. Working memory is also used for conscious operations such as recognition and decision making. Search for ideas in associative memory posits that the ideation process is a controlled associative process that contains two stages. In the first stage, a search cue, resulting from external stimuli and one's own modification, leads to the activation of images within long term memory. Such activation is probabilistic and the probability is dependent on the association between the search cue and the concepts of the image. The activated image will be loaded into working memory and therefore the concepts and associations of the image are available. In the second stage, the activated image in working memory is used to form new associations and combinations or to be applied in a new domain. Consequently an idea will be generated. This model indicates that stimuli, long term memory and working memory are three major factors in idea generation. 
A similar theory, called the cognitive network model of creativity (Santanen et al., 2004), also assumes that knowledge in the mind is a rich and highly interconnected network. When people encounter an external stimulus, it activates knowledge in mind and additional knowledge is activated in succession through associative links. Then, as a second step, the combination of knowledge from different areas of knowledge network leads to creative ideas. The combination of more distant knowledge may produce ideas of higher originality but may lead to higher cognitive load. This model contends that creative ideas result from new associations in the working memory of unrelated knowledge. The probability of forming such new associations is positively related to the difference among activated knowledge. Diversity of stimuli positively affects the difference among active knowledge. This model suggests that providing diverse and unrelated stimuli may improve idea originality.

Some stage theories argue that creativity is similar to biological evolution. Campbell (1960) posits that two types of mechanisms are behind creative thought: one that produces wide and frequent variations of ideas and the other for the selection of the variations. In other words, in a creative process, a large variety of cognitive elements and candidate ideas emerge, and then the most practical or useful candidates survive the selection. Similarly, Simonton (1989) proposes the "chance-configuration" theory to account for scientific creativity. The key notions of the theory are: 1) the chance permutation (or combination) of mental elements (such as concepts, facts, images, recollections); 2) the production of configurations, i.e. stable permutations; 3) the communication and external acceptance of the configurations. These evolutionary theories of creativity would suggest creativity support systems support random variation and combination of mental elements. Somewhat similarly, the Geneplore model proposes two stages in the creative process (Finke et al., 1992). In the generative phase, memory retrieval, association and analogical transfer lead to mental representations called preinventive structure. In the exploratory phase, the attribute finding and interpretation about the preinventive structure lead to meaningful creative outcome. 
The model proposed by Wallas (1926) states that the creative process has four stages: preparation (clarifying situation, reviewing relevant information etc.), incubation (pause of conscious effort), illumination (“Aha!" experience), and verification (analyze and validate the solution). Amabile (1996) proposes that creative process has four phases: problem identification, preparation (collecting information and resources), response generation and response validation and communication. The Osborn-Parnes Creative Problem Solving Process is a six-step structured method to solve problems creatively (Treffinger, 1995). The six steps are: mess-finding (discovering challenges), fact-finding, problemfinding, idea-finding, solution-finding (refining ideas and transforming them into solutions) and acceptance-finding. The creative problem solving process is characterized by the alternate use of divergent and convergent thinking in each of the six steps. The creative solving process model has undergone various modifications. A recent derivative contains six stages: exploring visions, formulating challenges, exploring ideas, formulating solutions, exploring acceptance and formulating a plan (Puccio, Murdock \& Mance, 2007). The stages do not need to be followed in a linear manner. Instead, at the end of each stage, a diagnosis step may be used to determine which stage to follow (Puccio et al., 2007). All these stage theories would suggest creativity support systems provide structured processes and support each step in them.

\subsection{Miscellaneous Theories}

Shneiderman (2002) offers an eclectic account of creativity. Structuralists believe that creativity can be achieved by following a structured method, which often contains several stages. In contrast, inspirationalists believe that creative solutions result from breaking away from established structures, through unrelated stimuli, dreaming and meditation. Situationalists stress the social nature of creative work. They investigate the motivations and social relationships of the creators. Each of the three views offers insights for designing individual creativity support systems (Shneiderman, 2002). The structuralist view would lead to tools that systematically constrain the creative process while the inspirationalist view 
advocates the usage of images, sketching interfaces and unrelated stimuli. The situationalist view would lead to systems that focus on incentives and motivation.

Boden (2004) argues that there are three ways to generate creative outcomes: combinational creativity, exploratory creativity and transformational creativity. Combinational creativity results from unfamiliar combinations of familiar ideas. Creativity can also be generated through the exploration of a conceptual space, which is defined by a set of rules. In transformational creativity, through changing a conceptual space's defining dimensions, the space is transformed and fundamentally different ideas emerge. This theory indicates creativity support systems should enable or automate the combination of ideas, the identification and search of conceptual spaces, as well as the transformation of conceptual spaces. Wiggins (2006) further formalizes the notion of exploratory and transformational creativity and shows the utility of such formalization in categorizing creative behavior.

A new model has been proposed to describe individual creativity (Seo et al., 2014). Specifically, the authors did a survey to verify the notion that creative self-efficacy, individual knowledge and IT support affect individual creativity through mediating variables: individual absorptive capacity, exploration and exploitation. This theory suggests that creativity support systems should support both exploration and exploitation, as well as improve people's absorptive capacity.

All of the above theories have possible applicability to the design of creativity support systems, but they are not in a form that can be easily operationalized and incorporated into tools. The next section discusses ways in which the theories can guide the design of individual creativity support systems.

\section{A New Framework for Designing Individual Creativity Support Systems}

The various creativity theories make it clear that creativity is a multi-faceted phenomenon and a creativity support system should consider its different aspects. It is useful to integrate the various insights from creativity theories into frameworks to inform the design of creativity support systems. As an attempt in this effort, we propose a domain general framework for individual creativity support systems (shown in Table 3). In developing this framework, we recognize that it is impractical to consult every creativity 
theory to the same degree. In selecting theories to focus on, we intend to 1) cover all the four categories in creativity theories (as in Table 2); 2) stress theories that have strong implications for building creativity support systems; and 3) center on theories that are frequently cited. When possible, we also try to emphasize theories that were published recently in order to reflect current understanding of creativity. Specifically, while many theories are consulted, the following theories have major influences on the framework: the componential theory of creativity (Amabile, 1983), the dual pathway to creativity theory (Nijstad et al., 2010), the associative theory of creativity (Mednick, 1962), Osborn-Parnes creative problem solving process (Treffinger, 1995), the search for ideas in associative memory theory (Nijstad \& Stroebe, 2006), and the three views on creativity (Shneiderman, 2002). Based on these theories, we identify four main aspects in creativity support: motivation for the creative task, a structured creative process, divergent thinking and convergent thinking.

Table 3. A Framework for Designing Individual Creativity Support Systems

\begin{tabular}{|l|l|l|}
\hline Aspects & Components & Features to Support the Component \\
\hline Motivation & Motivational priming & $\begin{array}{l}\text { Affective priming } \\
\text { Achievement priming }\end{array}$ \\
\hline $\begin{array}{l}\text { Creative } \\
\text { Process }\end{array}$ & Process completeness & $\begin{array}{l}\text { Modules to support each step in a complete creative } \\
\text { process }\end{array}$ \\
\cline { 2 - 3 } & Process control & $\begin{array}{l}\text { Allowing process planning, } \\
\text { Allowing iteration and selection of steps }\end{array}$ \\
\hline \multirow{3}{*}{$\begin{array}{l}\text { Divergent } \\
\text { thinking }\end{array}$} & Stimuli & $\begin{array}{l}\text { Providing different levels of stimuli, } \\
\text { Providing stimuli dynamically }\end{array}$ \\
\cline { 2 - 3 } & Long term memory & $\begin{array}{l}\text { External long term memory, such as knowledge base } \\
\text { and case library; } \\
\text { Facilitating search }\end{array}$ \\
\cline { 2 - 3 } & Working memory & $\begin{array}{l}\text { Supporting association, } \\
\text { Visualization, } \\
\text { Random combination }\end{array}$ \\
\cline { 2 - 3 } & Creativity techniques & $\begin{array}{l}\text { Facilitating the use of creativity techniques; } \\
\text { Computational creativity techniques }\end{array}$ \\
\hline $\begin{array}{l}\text { Convergent } \\
\text { thinking }\end{array}$ & Comprehension & Labeling, classification, simulation \\
\cline { 2 - 3 } & Decision & Criteria based comparison, Decision support \\
\hline
\end{tabular}


The componential theory of creativity contends that task motivation is an important component in creativity. Similarly, Shneiderman (2002) argues that the situationalist view of creativity emphasizes the role of motivation in creative work. Consequently, we argue that the first aspect of a creativity support system is to have features, such as motivational priming, to support task motivation. One example of motivational priming is affective priming. For example, showing a picture of laughing baby, leads to positive affect and improved creative performance (Lewis et al., 2011). Another instance of motivational priming is a game to form sentences from words associated with achievement. An example sentence is "Scholar aspires for honor". Such achievement priming has been shown to improve creativity (Dennis et al., 2013).

The second aspect of the framework is about supporting a structured creative process. The stage theories suggest that creativity support systems should ideally support all the stages in a creative process. As Mueller-Wienbergen and colleagues (2011) point out, the design theories for creativity support systems usually neglect convergent thinking. In addition, problem construction, another activity in the creative process, is only occasionally mentioned in the literature (Candy \& Edmonds, 1996; MacCrimmon \& Wagner, 1992). Without support for convergent thinking, creativity support systems users may have to manually screen lists of ideas or artifacts to find the best ones. This can be overly demanding, especially when a well-supported divergent thinking process has generated many ideas. Upstream in the creative process, if there is no support for problem construction, systems users are likely to forget this step. Since problem construction is shown to improve creative outcomes (Redmond, Mumford, \& Teach, 1993), supporting problem construction, or problem finding, can potentially promote creativity. Although the literature provides diverse descriptions of the structure of a complete creative process, the following four stages are often mentioned: problem finding (Amabile, 1996; Gabriel et al., 2016; Treffinger, 1995), information finding (Amabile, 1996; Shneiderman, 2002; Treffinger, 1995), idea finding (Amabile, 1996; Gabriel et al., 2016; Treffinger, 1995), and solution finding (Althuizen \& Reichel, 2016; Marakas \& Elam, 1997; Treffinger, 1995). While other activities can be important (for 
example, incubation and acceptance finding), the four stages mentioned above are most common in both theoretical analysis and practice. Each stage may have both divergent and convergent steps (Puccio et al., 2007; Treffinger, 1995). The structure of a complete creative process is illustrated in Table 4. Ideally all the eight steps can be supported by information systems.

In addition to allowing a complete creative process, an individual creativity support system should give user control over the process. This notion is consistent with the aforementioned IPC model that suggests control as one of the key components in computational creativity. A creative process is commonly iterative, with a lot of trials and errors (Puccio et al., 2007). Therefore, a system should not only enable users to plan the process in advance, but also show progress along the way and allow reflection, iteration and selection of steps.

Table 4. The Steps in a Complete Creative Process

\begin{tabular}{|c|c|c|}
\hline Process Stage & The Divergent Step & The Convergent Step \\
\hline Problem finding & $\begin{array}{l}\text { Formulating problem } \\
\text { presentations in various } \\
\text { ways }\end{array}$ & $\begin{array}{l}\text { Selecting the best ways to } \\
\text { present the problem }\end{array}$ \\
\hline Information finding & $\begin{array}{l}\text { Collecting potentially } \\
\text { relevant information }\end{array}$ & $\begin{array}{l}\text { Selecting the most relevant } \\
\text { information }\end{array}$ \\
\hline Idea finding & Generating many ideas & Selecting the best ideas \\
\hline Solution finding & Improving the selected ideas & $\begin{array}{l}\text { Selecting the improved ideas } \\
\text { and integrating them into a } \\
\text { solution }\end{array}$ \\
\hline
\end{tabular}

The third aspect in our framework is the support of divergent thinking. As the major source of originality, divergent thinking needs to be supported in various ways. In the search for ideas in associative memory model, ideation proceeds with the activation of knowledge in long term memory upon search cues, which can be a problem or some stimuli, and consequent processing of activated knowledge in working memory that leads to new associations, combinations and in turn, ideas (Nijstad \& Stroebe, 2006). Therefore, the first component in supporting divergent thinking is to provide stimuli that will be used as search cues. It needs to be noted that not all stimuli are effective in promoting creativity. For example, the trend to fixate on features from design examples can be harmful to design creativity 
(Jansson \& Smith, 1991). Furthermore, in an experiment on knowledge reuse, seeing previous ideas reduced creative performance (Cheung et al., 2008). Therefore, identifying useful stimuli for creative tasks is an important research topic. The dual pathway to creativity theory suggests that creativity can result from deep exploration of one category or broad exploration of diverse categories (Nijstad et al., 2010). Consequently, a creativity support system may be effective either through providing many stimuli in one category, or through providing stimuli across various categories.

The second component in supporting divergent thinking is to provide an external long term memory which is easily searchable. This can be realized by (1) including or providing access to domainspecific knowledge, such as knowledge bases and other online resources; (2) having a user-extendable library of previous ideas, cases or solutions (Althuizen \& Wierenga, 2014; Dominowski \& Dallob, 1996; Herring et al., 2009; Hewett, 2005); (3) enabling effective search of the knowledge and information above (Jenkin, Chan, Skillicorn, \& Rogers, 2013). In this way, the function of long term memory, providing mental elements for ideation, is supplemented. Some online knowledge bases are free, comprehensive and increasingly popular such as WordNet, Wikipedia and Freebase. These knowledge bases are often structured, which facilitates computational approach for retrieving knowledge, supporting creativity, and possibly automatic generation of creative outcomes. In addition, many online resources, while not designed as knowledge bases, can be mined for elements useful for creative work, such as websites for crowdsourced product design and social media. The growing amount of data in the Internet and its accessibility enable new opportunities in devising creativity support systems. Moreover, new approaches for retrieving relevant knowledge (e.g., Jenkin et al., 2013) can be applied to various sources of external knowledge and provide raw materials for creative work.

The third component in supporting divergent thinking is to support the function of working memory, which include temporary information storage, combination, association and other information processing. Association is a key activity in creativity as suggested by the associative theory of creativity (Mednick, 1962). Making associations can be supported by computerized mind-mapping (Althuizen \& 
Reichel, 2016). Furthermore, individual creativity support systems may help visualize knowledge to facilitate understanding and exploration (Candy, 1997). Visualizing associations and prompting people to extend associations may help retrieve remote information. According to chance-configuration theory (Simonton, 1989), random combination of mental elements plays an important role in creative thinking. Therefore, individual creativity support systems may provide random combinations of concepts or notions based on users' input, which helps working memory in making new combinations and generating new ideas.

Finally, using creative techniques or heuristics is the fourth component to promote divergent thinking. A creativity technique is "a plausibly effective prescription expressing more than common knowledge" to improve creativity (Smith, 1998). Many creativity techniques have been developed and studied (Couger, 1995; vanGundy, 1988). As Shneiderman (2002) suggests, structuralists and inspirationalists have different views on creativity. Relatedly, creativity techniques can be classified into two types: intuitive techniques and analytical techniques (Couger, 1995), corresponding to the inspirationalist view and the structuralist view of creativity, respectively. Intuitive techniques, such as guided fantasy (Garfield et al., 2001) and random stimulation, stress randomness, imagery, and taking a leap. Analytical techniques try to benefit creativity through structure and templates, for example, force field analysis (Garfield et al., 2001), Theory of Inventive Problem Solving (TRIZ) (Howard, Culley \& Dekoninck, 2011), and templates for advertisement and new product ideas (Goldenberg et al, 1999b, c). Both analytical and intuitive techniques are considered effective in promoting creativity (Couger, 1995; Couger et al., 1993). Consequently, it should be useful to enable the usage of these techniques in creativity support systems. In addition, labeling analytical and intuitive techniques as such can facilitate the selection of creativity techniques.

Furthermore, many computational creativity techniques have been developed, e.g. computational generation of analogy (Veale, 2006; Young, 1987) and graphic design (Hung \& Choy, 2013). These techniques enable a computer to generate creative outcome by itself. We envision more applications of 
these creative approaches in creativity support systems and more synergy among the power of computing, heuristics, and human mind.

In each divergent step, a big pool of items (e.g., pieces of information and ideas) is generated. The final aspect of an individual creativity support system is about the selection of the best items by supporting convergent thinking. This can be achieved through the support for comprehension of selection candidates and the support for decision making. Comprehension can be supported through the labeling, clustering, and categorization of items. For example, Viriyayudhakorn and Kunifuji (2013) propose to automatically identify topics of ideas based on some knowledge bases. In addition, if appropriate models are available, running simulations can also help users to understand candidate items (Avital \& Te'eni, 2009; Shneiderman, 2002). Decision making can be supported through 1) prompting the generation of criteria for evaluation; 2) enabling the evaluation and selection of items based on identified criteria. In addition, there is a body of literature on decision support systems (Eom \& Kim, 2006). Many decision support approaches can potentially facilitate convergent thinking.

\section{Future Research}

Within the new framework presented above, there are some research topics that appear promising. This section aims at elaborating on such future research topics.

As mentioned before, providing stimuli is an important way to support divergent thinking. Both the cognitive network model of creativity (Santanen et al., 2004) and the bisociation theory (Koestler, 1964) suggest that creative ideas come from connecting unrelated knowledge or notions. Indeed, exposure to unrelated items is shown to increase the originality of output (Kohn, Paulus, \& Korde, 2011). However, we want to stress that using only unrelated stimuli may not be optimal. For example, McCaffrey and Spector (2011) argue that innovations are commonly based on features of problems or related entities that are moderately distant. This is because features that are too closely related are unlikely to lead to innovation while features that are too foreign are less likely to be useful. In another study, seeing an original idea reduces people's ability to think fluently (Wang, Nickerson, \& Sakamoto, 2013). Since it is 
often hard to know a priori which level of stimuli relevance is optimal for a creative task, it would be ideal for a creativity support system to provide different levels of stimuli. Providing different levels of stimuli may facilitate both exploration and exploitation, which would be ideal for creativity (Seo et al., 2014). Similarly, Knoll and Horton (2011) argue that both related and unrelated stimuli are needed so that all three types of mental operations: jumping, dumping and pumping, are supported. Indeed, a case-based creativity support system is shown to be more effective when it contains both closely related and remote cases (Althuizen \& Wierenga, 2014). Therefore, an important research question is: how can we automatically identify stimuli of different levels of relatedness. Building or employing a semantic network may be a solution. Some existing semantic networks that are potentially useful include WordNet and Wikipedia. Using these semantic networks, semantic distance between concepts can be estimated by various measures, such as the number of associative steps or the relationship within a category structure. This approach has the potential to enable automatic retrieval of stimuli of different levels of relevance. In addition, according to dual coding theory, there are two independent associative networks in mind: verbal and non-verbal (Paivio \& Lambert, 1981). To take advantage of both networks, both verbal and nonverbal stimuli should be provided. The aforementioned semantic networks may be explored to retrieve concepts of different levels, then these concepts can be used to search for photos to be used as stimuli in creative tasks.

In addition, we propose that creativity support systems should provide stimuli dynamically. Specifically, we argue that in sampling idea space, it is sensible to first sample widely and more randomly and then focus on some promising ideas and think deeper about them. Therefore, providing unrelated stimuli in the beginning and related stimuli in later stage of ideation should be advantageous. Providing stimuli dynamically is consistent with Gabora's theory (2002) that suggests the creative process has two stages that contain distinct activities. In the first stage, defocused attention and novel associations are better served with diverse and remote stimuli. In the second stage of focused and logical thinking, remote associations and strange new combinations can be a distraction (Gabora, 2002). Instead, focused thinking 
is better served with related stimuli. Similarly, for the generation of preinventive structure (Finke et al., 1992), diverse and remote stimuli may be beneficial. But for exploratory stage, related stimuli should be more beneficial for attribute finding and interpretation. The benefit of dynamically providing stimuli can be experimentally tested in creativity support systems.

There is a lack of research on the support of problem finding, or problem construction, in creativity support systems. Some empirical results from other research areas can inform the design of this function. Sequentially presenting decomposed problems is likely to be a good approach since it is shown to lead to more ideas than presenting only the overall problem (Dennis et al., 1996), or simultaneous presentation of decomposed problems (Coskun, Paulus, Brown, \& Sherwood, 2000). People's preference towards constructing problems in terms of restrictions and problem solving procedures is positively related to creative problem solving performance (Mumford, Baughman, Threlfall, Supinski, \& Costanza, 1996). Therefore, it may be beneficial to guide system users to construct problems focusing on these two aspects. One problem construction heuristic is to iteratively ask "why" and "what's stopping you" so that a web of questions can be identified (Ellspermann, Evans, \& Basadur, 2007). This approach has been shown to lead to higher number and quality of problem statements. A similar heuristic is to iteratively ask for the purpose of solving a problem. This approach is shown to improve problem solving performance (Volkema, 1983). All these problem construction methods may be included in a creativity support system. Lastly, as outlined in the new framework, the problem finding stage can have a divergent step followed by a convergent step. Therefore, all the techniques for supporting divergent thinking are potentially useful for supporting the divergent step in problem finding. For example, we may provide various stimuli to help users construct many problem statements, which are later screened to identify best ways to define the problem. These various problem finding approaches may be empirically tested in creativity support systems.

Finally, it is worthwhile to study the effect of individual differences in the use of creativity support systems. According to the 4-Ps theory (Rhodes, 1961), the creative person is among the key 
aspects of creativity. However, this person aspect receives less attention in the literature of individual creativity support systems. Among the few studies that explored this aspect, there are conflicting findings. Specifically, who do creativity support systems benefit more: the highly creative or the less creative? While MacCrimmon and Wagner (1994) reported that the highly creative benefited more, other researchers found that the highly creative showed a reduced creative performance when they used a creativity support system (Althuizen \& Wierenga, 2014; Cheung et al., 2008). These results suggest that 1) there is an interaction between individual differences and the use of creativity support systems; 2) there are likely moderating variables that have not been tested yet. The Kirton's cognitive style, i.e. adaptor vs. innovator (Kirton, 1976), may influence the use of creativity support systems (Garfield et al., 2001; Nagasundaram \& Bostrom, 1994). Another personal difference is the personal preference for different stages in a creative process, e.g., problem construction. This preference can be measured by an inventory called FourSight (Puccio, Wheeler \& Cassandro, 2004). These personal differences, in addition to creative ability, might interact with different aspects in creativity support, such as the type of stimuli and creativity techniques used. In general, we contend that creativity support is most effective when it supports a weak or neglected aspect for a user. For example, if a user tends to neglect the problem construction stage in a creative process, then a system supporting this stage tends to be more useful for this user. Because there are many personal differences and many creativity support approaches, there are potentially numerous interaction effects to explore. Improved understanding of these interaction effects will inform better design of individual creativity support systems, as well as improve our understanding of creativity and innovation. In addition, while there are numerous studies on the adoption of information systems, the adoption of individual creativity support systems seems to be less researched (Wang, 2014). The understanding of these interaction effects is likely to help improve the adoption of individual creativity support systems in the business world.

\section{Conclusion}


Creativity support systems have been shown to improve creative output (MacCrimmon \& Wagner, 1994; Malaga, 2000; Marakas \& Elam, 1997). This article reviewed the studies on individual creativity support systems and relevant creativity theories. Numerous designs and approaches of individual creativity support systems have been proposed in the literature. They typically support the creation of ideas or artifacts but ignore problem construction or problem finding. We proposed a new framework for the design of individual creativity support systems that enumerated aspects, components, and features. We believe that it is important to support not only task motivation, but also to support a complete creative process consisting of both divergent and convergent steps. We identified areas for future research, including support for problem finding, the automatic retrieval of stimuli of different levels, ways of providing stimuli dynamically, and studying the effect of users' individual differences. Research on creativity support systems provides a way to integrate and test different theories related to creativity, and we expect that not only will new research on creativity show up in future systems, but the systems themselves will provide platforms to test theories, practices based on these theories, and their interactions. 


\section{Appendix. Empirical Studies on Individual Creativity Support Systems}

\begin{tabular}{|c|c|c|c|c|}
\hline Article & System Name & Approach & Domain & Stage \\
\hline $\begin{array}{l}\text { Aihara \& Hori, } \\
1998\end{array}$ & En Passant 2 & $\begin{array}{l}\text { Organize research notes and } \\
\text { trigger recalls }\end{array}$ & Domain general & $\begin{array}{l}\text { Information } \\
\text { finding }\end{array}$ \\
\hline $\begin{array}{l}\text { Althuizen \& } \\
\text { Reichel } 2016\end{array}$ & $\begin{array}{l}\text { ThoughtpathTM, } \\
\text { MindMapper, } \\
\text { IdeaFisher }\end{array}$ & $\begin{array}{l}\text { Process guide, mind mapper, } \\
\text { stimuli provider }\end{array}$ & Domain general & $\begin{array}{l}\text { Problem finding, } \\
\text { idea finding, } \\
\text { solution finding; } \\
\text { idea finding; } \\
\text { idea finding }\end{array}$ \\
\hline $\begin{array}{l}\text { Althuizen \& } \\
\text { Wierenga, } 2014\end{array}$ & N/A & Case based reasoning & Domain general & $\begin{array}{l}\text { Information } \\
\text { finding, idea } \\
\text { finding, solution } \\
\text { finding }\end{array}$ \\
\hline $\begin{array}{l}\text { Brade, Heseler, } \\
\& \text { Groh, } 2011\end{array}$ & BrainDump & \begin{tabular}{|l|} 
Visualize associations and \\
organization of information
\end{tabular} & Domain general & $\begin{array}{l}\text { Information } \\
\text { finding }\end{array}$ \\
\hline Chen, 1996 & N/A & $\begin{array}{l}\text { Generate suggestions using } \\
\text { analogical reasoning through } \\
\text { document structure mapping }\end{array}$ & Domain general & $\begin{array}{l}\text { Idea finding, } \\
\text { solution finding }\end{array}$ \\
\hline $\begin{array}{l}\text { Cheung et al., } \\
2008\end{array}$ & N/A & $\begin{array}{l}\text { Use a Web-based knowledge } \\
\text { repository to promote creative } \\
\text { thinking }\end{array}$ & Domain general & $\begin{array}{l}\text { Information } \\
\text { finding, idea } \\
\text { finding, solution } \\
\text { finding }\end{array}$ \\
\hline $\begin{array}{l}\text { Dennis, Minas, } \\
\text { \& Bhagwatwar, } \\
2013\end{array}$ & N/A & $\begin{array}{l}\text { Use a simple computer game to } \\
\text { implement achievement } \\
\text { priming }\end{array}$ & Domain general & Idea finding \\
\hline $\begin{array}{l}\text { Elam \& Mead, } \\
1990\end{array}$ & ods/CONSULTANT & $\begin{array}{l}\text { Use questions to guide users } \\
\text { through a complete creative } \\
\text { process }\end{array}$ & Domain general & $\begin{array}{l}\text { Problem finding, } \\
\text { information } \\
\text { finding, idea } \\
\text { finding, solution } \\
\text { finding }\end{array}$ \\
\hline $\begin{array}{l}\text { Fentem, Dumas, } \\
\& \text { McDonnell, } \\
1998\end{array}$ & N/A & $\begin{array}{l}\text { Spatial representations of } \\
\text { strategic knowledge in the } \\
\text { form of maps }\end{array}$ & Domain general & $\begin{array}{l}\text { Information } \\
\text { finding, idea } \\
\text { finding }\end{array}$ \\
\hline $\begin{array}{l}\text { Forgionne \& } \\
\text { Newman,2007 }\end{array}$ & CDMSS & $\begin{array}{l}\text { In addition to a regular } \\
\text { decision support system, } \\
\text { provide creativity enhancing } \\
\text { tools that visualize and } \\
\text { organize ideas. }\end{array}$ & Domain general & $\begin{array}{l}\text { Problem finding, } \\
\text { information } \\
\text { finding, idea } \\
\text { finding, solution } \\
\text { finding }\end{array}$ \\
\hline $\begin{array}{l}\text { Garfield et al., } \\
2001\end{array}$ & N/A & $\begin{array}{l}\text { Use different creativity } \\
\text { techniques, show others' ideas }\end{array}$ & Domain general & Idea finding \\
\hline $\begin{array}{l}\text { Jenkin et al., } \\
2013\end{array}$ & NID & \begin{tabular}{|l|} 
Identify novel yet relevant \\
information by iteratively \\
search the Internet using newly \\
found keywords
\end{tabular} & Domain general & $\begin{array}{l}\text { Information } \\
\text { finding, idea } \\
\text { finding }\end{array}$ \\
\hline $\begin{array}{l}\text { Koh, Kerne, \& } \\
\text { Hill, } 2007\end{array}$ & combinFormation & $\begin{array}{l}\text { Gather and present relevant } \\
\text { information visually to } \\
\text { facilitate information discovery } \\
\text { and exploratory search }\end{array}$ & Domain general & $\begin{array}{l}\text { Information } \\
\text { finding }\end{array}$ \\
\hline $\begin{array}{l}\text { Lewis, } \\
\text { Dontcheva, \& } \\
\text { Gerber, } 2011\end{array}$ & N/A & $\begin{array}{l}\text { Show pictures to induce } \\
\text { positive affect }\end{array}$ & Domain general & Idea finding \\
\hline
\end{tabular}




\begin{tabular}{|c|c|c|c|c|}
\hline $\begin{array}{l}\text { Lopes, Alvarez- } \\
\text { Napagao, \& } \\
\text { Vazquez- } \\
\text { Salceda, } 2009 \\
\end{array}$ & USE & $\begin{array}{l}\text { A system for recommending } \\
\text { tagged pictures from the Web, } \\
\text { which can help brainstorming }\end{array}$ & Domain general & $\begin{array}{l}\text { Information } \\
\text { finding }\end{array}$ \\
\hline $\begin{array}{l}\text { MacCrimmon \& } \\
\text { Wagner, } 1994\end{array}$ & GENI & $\begin{array}{l}\text { Provide different types of } \\
\text { stimuli, support the connection } \\
\text { of different elements in a } \\
\text { problem }\end{array}$ & Domain general & $\begin{array}{l}\text { Problem finding, } \\
\text { idea finding, } \\
\text { solution finding }\end{array}$ \\
\hline Malaga, 2000 & N/A & $\begin{array}{l}\text { Use picture and word stimuli to } \\
\text { promote creative thinking }\end{array}$ & Domain general & Idea finding \\
\hline $\begin{array}{l}\text { Marakas \& } \\
\text { Elam, } 1997\end{array}$ & od/CONSULTANT & $\begin{array}{l}\text { Guide users through a series of } \\
\text { steps in a creative process }\end{array}$ & Domain general & $\begin{array}{l}\text { Problem finding, } \\
\text { information } \\
\text { finding, idea } \\
\text { finding, solution } \\
\text { finding }\end{array}$ \\
\hline Massetti, 1996 & IdeaFisher, Ideatree & $\begin{array}{l}\text { Provide stimuli such as topics, } \\
\text { phrases, questions; Mind } \\
\text { mapping }\end{array}$ & Domain general & Idea finding \\
\hline $\begin{array}{l}\text { Mueller- } \\
\text { Wienberen et al., } \\
2011\end{array}$ & N/A & $\begin{array}{l}\text { A set of measures is proposed } \\
\text { to support Divergent and } \\
\text { Convergent thinking }\end{array}$ & Domain general & $\begin{array}{l}\text { Information } \\
\text { finding, idea } \\
\text { finding }\end{array}$ \\
\hline $\begin{array}{l}\text { Olteteanu \& } \\
\text { Falomir, } 2016\end{array}$ & OROC & $\begin{array}{l}\text { Use object replacement and } \\
\text { object composition to generate } \\
\text { ideas automatically }\end{array}$ & Domain general & Idea finding \\
\hline $\begin{array}{l}\text { Santanen, } \\
\text { Briggs, \& de } \\
\text { Vreede, 2004 }\end{array}$ & N/A & $\begin{array}{l}\text { Provide stimuli such as } \\
\text { suggestions to inspire ideas }\end{array}$ & Domain general & Idea finding \\
\hline $\begin{array}{l}\text { Viriyayudhakorn, } \\
\text { Kunifuji, \& } \\
\text { Ogawa, } 2011\end{array}$ & Eureka! & $\begin{array}{l}\text { Provide Wikipedia-based } \\
\text { stimuli }\end{array}$ & Domain general & Idea finding \\
\hline $\begin{array}{l}\text { Alvarez \& Su, } \\
2012\end{array}$ & VRMDS & $\begin{array}{l}\text { Virtual environment for } \\
\text { supporting the conceptual } \\
\text { design of mechanisms. 3D } \\
\text { modelling and prototyping }\end{array}$ & $\begin{array}{l}\text { Engineering } \\
\text { design and } \\
\text { innovation }\end{array}$ & $\begin{array}{l}\text { Idea finding, } \\
\text { solution finding }\end{array}$ \\
\hline Chen, 1999 & N/A & $\begin{array}{l}\text { Use computational methods to } \\
\text { realize heuristics for technical } \\
\text { invention }\end{array}$ & $\begin{array}{l}\text { Engineering } \\
\text { design and } \\
\text { innovation }\end{array}$ & $\begin{array}{l}\text { Idea finding, } \\
\text { solution finding }\end{array}$ \\
\hline $\begin{array}{l}\text { Gomes et al., } \\
2006\end{array}$ & REBUILDER & $\begin{array}{l}\text { Use analogies to support } \\
\text { software design. Structure of } \\
\text { design diagrams is used to } \\
\text { retrieve analogies from a case } \\
\text { library }\end{array}$ & $\begin{array}{l}\text { Engineering } \\
\text { design and } \\
\text { innovation }\end{array}$ & $\begin{array}{l}\text { Information } \\
\text { finding, idea } \\
\text { finding, solution } \\
\text { finding }\end{array}$ \\
\hline Hori, 1997 & N/A & $\begin{array}{l}\text { Visualize the concept space of } \\
\text { design }\end{array}$ & $\begin{array}{l}\text { Engineering } \\
\text { design and } \\
\text { innovation }\end{array}$ & $\begin{array}{l}\text { Problem finding, } \\
\text { information } \\
\text { finding, idea } \\
\text { finding }\end{array}$ \\
\hline $\begin{array}{l}\text { McCaffrey \& } \\
\text { Spector, } 2011\end{array}$ & Innovation assistant & $\begin{array}{l}\text { Use a semantic network of } \\
\text { physical features to guide users } \\
\text { to obscure features. }\end{array}$ & $\begin{array}{l}\text { Engineering } \\
\text { design and } \\
\text { innovation }\end{array}$ & $\begin{array}{l}\text { Information } \\
\text { finding, idea } \\
\text { finding }\end{array}$ \\
\hline $\begin{array}{l}\text { Shai, Reich, \& } \\
\text { Rubin, } 2009\end{array}$ & N/A & $\begin{array}{l}\text { Generate design solutions by } \\
\text { using designs from remote } \\
\text { disciplines. }\end{array}$ & $\begin{array}{l}\text { Engineering } \\
\text { design and } \\
\text { innovation }\end{array}$ & $\begin{array}{l}\text { Idea finding, } \\
\text { solution finding }\end{array}$ \\
\hline
\end{tabular}




\begin{tabular}{|c|c|c|c|c|}
\hline $\begin{array}{l}\text { Sugimoto, Hori, } \\
\& \text { Ohsuga, } 1994\end{array}$ & N/A & $\begin{array}{l}\text { Visualize viewpoints and their } \\
\text { semantic relationships }\end{array}$ & $\begin{array}{l}\text { Engineering } \\
\text { design and } \\
\text { innovation }\end{array}$ & $\begin{array}{l}\text { Idea finding, } \\
\text { solution finding }\end{array}$ \\
\hline $\begin{array}{l}\text { Vattam et al., } \\
2010\end{array}$ & DANE & $\begin{array}{l}\text { Provide a design case library of } \\
\text { biological systems }\end{array}$ & $\begin{array}{l}\text { Engineering } \\
\text { design and } \\
\text { innovation }\end{array}$ & $\begin{array}{l}\text { Idea finding, } \\
\text { solution finding }\end{array}$ \\
\hline $\begin{array}{l}\text { Zanni-Merk, } \\
\text { Cavallucci, \& } \\
\text { Rousselot, 2009 }\end{array}$ & N/A & $\begin{array}{l}\text { Develop an ontology for } \\
\text { computer aided innovation } \\
\text { with TRIZ }\end{array}$ & $\begin{array}{l}\text { Engineering } \\
\text { design and } \\
\text { innovation }\end{array}$ & $\begin{array}{l}\text { Idea finding, } \\
\text { solution finding }\end{array}$ \\
\hline $\begin{array}{l}\text { Hung \& Choy, } \\
2013\end{array}$ & N/A & $\begin{array}{l}\text { Use conceptual recombination } \\
\text { to transform unfinished } \\
\text { creative work into final output }\end{array}$ & Graphic design & $\begin{array}{l}\text { Idea finding, } \\
\text { solution finding }\end{array}$ \\
\hline $\begin{array}{l}\text { Sedivy \& } \\
\text { Johnson, } 2000\end{array}$ & Speak 'n' Sketch & $\begin{array}{l}\text { Voice activation of } \\
\text { functionalities, supporting for } \\
\text { layers, allowing easy } \\
\text { manipulation on drawings }\end{array}$ & Graphic design & Idea finding \\
\hline $\begin{array}{l}\text { Hedblom, Kutz, } \\
\& \text { Neuhaus, } \\
2016\end{array}$ & N/A & $\begin{array}{l}\text { Use image schemas in } \\
\text { computational conceptual } \\
\text { blending }\end{array}$ & $\begin{array}{l}\text { Linguistic } \\
\text { creativity }\end{array}$ & Idea finding \\
\hline Veale, 2006 & N/A & $\begin{array}{l}\text { Computational retrieval of } \\
\text { analogies from WordNet }\end{array}$ & $\begin{array}{l}\text { Linguistic } \\
\text { creativity }\end{array}$ & Idea finding \\
\hline Young, 1987 & N/A & $\begin{array}{l}\text { A relational database method } \\
\text { for automatic metaphor } \\
\text { generation }\end{array}$ & $\begin{array}{l}\text { Linguistic } \\
\text { creativity }\end{array}$ & Idea finding \\
\hline $\begin{array}{l}\text { Chuan \& Chew, } \\
2007\end{array}$ & N/A & $\begin{array}{l}\text { Create accompaniment by } \\
\text { combining music knowledge, } \\
\text { human input, and statistical } \\
\text { learning. }\end{array}$ & $\begin{array}{l}\text { Musical } \\
\text { creativity }\end{array}$ & Idea finding \\
\hline $\begin{array}{l}\text { Riley, Alm, \& } \\
\text { Newell,2009 }\end{array}$ & N/A & $\begin{array}{l}\text { Develop a touch screen } \\
\text { interface to control chords and } \\
\text { create music }\end{array}$ & $\begin{array}{l}\text { Musical } \\
\text { creativity }\end{array}$ & Idea finding \\
\hline $\begin{array}{l}\text { Chakrabarti et } \\
\text { al., } 2005\end{array}$ & IdeaInspire & $\begin{array}{l}\text { Systematic biomimetics for } \\
\text { product development. } \\
\text { Automated analogical search of } \\
\text { ideas from databases }\end{array}$ & Product design & $\begin{array}{l}\text { Information } \\
\text { finding, idea } \\
\text { finding, solution } \\
\text { finding }\end{array}$ \\
\hline $\begin{array}{l}\text { Chang et al., } \\
2016\end{array}$ & Rhino5.0 & $\begin{array}{l}\text { 3D-CAD, its effect and } \\
\text { influence of representational } \\
\text { abilities. }\end{array}$ & Product design & $\begin{array}{l}\text { Idea finding, } \\
\text { solution finding }\end{array}$ \\
\hline $\begin{array}{l}\text { Gerber \& } \\
\text { Martin, } 2012\end{array}$ & N/A & $\begin{array}{l}\text { A set of design principles is } \\
\text { proposed, such as providing } \\
\text { challenge, autonomy, } \\
\text { supporting goal setting and } \\
\text { positive affect }\end{array}$ & Product design & $\begin{array}{l}\text { Idea finding, } \\
\text { solution finding }\end{array}$ \\
\hline Liu et al., 2011 & CACDP & $\begin{array}{l}\text { Use a knowledge base, a Web } \\
\text { searching tool, creative } \\
\text { methods and CAD tools to } \\
\text { support creative design }\end{array}$ & Product design & $\begin{array}{l}\text { Problem finding, } \\
\text { information } \\
\text { finding, idea } \\
\text { finding, solution } \\
\text { finding }\end{array}$ \\
\hline $\begin{array}{l}\text { Setchi \& } \\
\text { Bouchard, } 2010\end{array}$ & OntoTag & $\begin{array}{l}\text { Semantic based image retrieval } \\
\text { algorithm }\end{array}$ & Product design & Idea finding \\
\hline $\begin{array}{l}\text { Wang, Ohsawa } \\
\text { \& Nishihara, } \\
2012\end{array}$ & N/A & $\begin{array}{l}\text { Use scenario graph to support } \\
\text { idea generation; use an } \\
\text { innovators market game to } \\
\text { simulate a real market }\end{array}$ & Product design & $\begin{array}{l}\text { Information } \\
\text { finding, idea } \\
\text { finding }\end{array}$ \\
\hline
\end{tabular}




\begin{tabular}{|l|l|l|l|l|}
\hline $\begin{array}{l}\text { Wang \& } \\
\text { Ohsawa, 2013 }\end{array}$ & Galaxy & $\begin{array}{l}\text { Using data synthesis for } \\
\text { uncovering latent information } \\
\text { and its dynamic changes for } \\
\text { idea creation, integration and } \\
\text { evaluation. }\end{array}$ & Product design & $\begin{array}{l}\text { Information } \\
\text { finding, idea } \\
\text { finding }\end{array}$ \\
\hline
\end{tabular}




\section{References}

Aihara, K., \& Hori, K. 1998. Enhancing creativity through reorganising mental space concealed in a research notes stack. Knowledge-Based Systems, 11(7-8): 469-478. doi:10.1016/S09507051(98)00080-X

Althuizen, N., \& Wierenga, B. 2014. Supporting creative problem solving with a case-based reasoning system. Journal of Management Information Systems, 31(1): 309-340. doi:10.2753/MIS07421222310112

Althuizen, N., Reichel, A. 2016. The effects of IT-enabled cognitive stimulation tools on creative problem solving: A dual pathway to creativity. Journal of Management Information Systems, 33(1), 11-44.

Alvarez, J. C., \& Su, H. J. 2012. VRMDS: an intuitive virtual environment for supporting the conceptual design of mechanisms. Virtual Reality, 16(1), 57-68.

Amabile, T.M. 1983. Social psychology of creativity. New York: Springer-Verlag

Amabile, T.M. 1996. Creativity in context. Boulder, CO: Westview.

Avital, M., Te'eni, D. 2009.From generative fit to generative capacity: Exploring an emerging dimension of information systems design and task performance. Information Systems Journal, 19: 345-367.

Baer, M., Leenders, R. T. A. J., Oldham, G. R., \& Vadera, A. K. 2010. Win or Lose the Battle for Creativity: The Power and Perils of Intergroup Competition. Academy of Management Journal, 53: $827-845$.

Bawden, D. 1986. Information systems and the stimulation of creativity. Journal of Information Science, 12: 203-216.

Boden, M.A. 2004. The creative mind: Myths and mechanisms. London: Routledge.

Brade, M., Heseler, J., \& Groh, R. 2011. An Interface for Visual Information-Gathering during Web Browsing Sessions. The Fourth International Conference on Advances in Computer-Human Interactions, 112-119.

Brophy, D. R. 1998. Understanding, measuring, and enhancing collective creative problem-solving efforts. Creativity Research Journal, 11(3): 199-229. doi:10.1207/s15326934crj1103_2

Buzan, T., \& Buzan, B. 1996. The Mind Map Book: How to Use Radiant Thinking to Maximize Your Brain's Untapped Potential. New York: Plume.

Campbell, D.T. 1960. Blind variation and selective retentions in creative thought as in other knowledge processes. Psychological Review, 67: 380-400.

Candy, L., Edmonds, E.A. 1996. Creative design of the Lotus bicycle: Implications for knowledge support systems research. Design Studies, 17: 71-90.

Candy, L. 1997. Computers and creativity support: Knowledge, visualization and collaboration. Knowledge-Based Systems, 10: 3-13.

Chakrabarti, A., Sarkar, P., Leelavathamma, B., \& Nataraju, B. S. 2005. A functional representation for aiding biomimetic and artificial inspiration of new ideas. Artificial Intelligence for Engineering Design, Analysis and Manufacturing, 19(02), 113-132.

Chang, Y. S., Chien, Y. H., Lin, H. C., Chen, M. Y., \& Hsieh, H. H. 2016. Effects of 3D CAD applications on the design creativity of students with different representational abilities. Computers in Human Behavior, 65, 107-113.

Chaudhuri, S., \& Koltun, V. 2010. Data-Driven Suggestions for Creativity Support in 3D Modeling. ACM Transactions on Graphics, 29(6): 183-190.

Chen, Z. 1996. Generating suggestions through document structure mapping. Decision Support Systems, 16(4): 297-314. doi:10.1016/0167-9236(95)00024-0

Chen, Z. 1999. Retrospective analysis for knowledge-based idea generation of new artifacts. KnowledgeBased Systems, 12(7): 333-339. doi:10.1016/S0950-7051(99)00033-7

Cherry, E., \& Latulipe, C. 2014. Quantifying the creativity support of digital tools through the creativity support index. ACM Transactions on Computer-Human Interaction, 21(4): Article 21. 
Cheung, P.-K., Chau, P. Y. K., \& Au, A. K. K. 2008. Does knowledge reuse make a creative person more creative? Decision Support Systems, 45: 219-227.

Chuan, C. H., \& Chew, E. 2007. A hybrid system for automatic generation of style-specific accompaniment. Proceedings of the 4th International Joint Workshop on Computational Creativity, 57-64.

Chung, S., Lee, K. Y., \& Choi, J. 2014. Exploring digital creativity in the workspace: The role of enterprise mobile applications on perceived job performance and creativity. Computers in Human Behavior, 42: 93-109.doi:10.1016/j.chb.2014.03.055

Coskun, H., Paulus, P.B., Brown, V., \& Sherwood, J.J. 2000. Cognitive stimulation and problem presentation in idea-generating groups. Group Dynamics: Theory, Research, and Practice, 4: 307329.

Couger, J. D. 1995. Creative Problem Solving and Opportunity Finding. Hinsdale, IL: Boyd \& Fraser Publishing Company.

Couger, J.D., Higgins, L.F. , \& Mclntyre, S.C. 1993. (Un)Structured creativity in information systems organizations. MIS Quarterly, 17: 375-397.

Csikszentmihalyi, M. 2009. Creativity: Flow and the Psychology of Discovery and Invention. New York: HarperCollins.

Davis, G.A. 2004. Creativity is forever. Dubuque, IA: Kendall/Hunt.

Dennis, A. R., Minas, R. K., \& Bhagwatwar, A. P. 2013. Sparking creativity: Improving electronic brainstorming with individual cognitive priming. Journal of Management Information Systems, 29(4): 195-215. doi:10.2753/MIS0742-1222290407

Dennis, A.R., Valacich, J.S., Connolly, T. , \& Wynne, B.E. 1996. Process structuring in electronic brainstorming. Information Systems Research, 7: 268-277.

Dominowski, R.L., \& Dallob, P. 1996. Insight and problem solving. In R.J. Sternberg and J.E. Davidson (Eds.), The Nature of Insight: 273-278. Cambridge, MA: MIT Press.

Eaglestone, B., Ford, N. , Brown, G.J. , \& Moore, A. 2007. Information systems and creativity: An empirical study. Journal of Documentation, 63: 443-464.

Elam, J. J., \& Mead, M. 1990. Can software influence creativity? Information Systems Research, 1(1): 121.

Ellspermann, S.J., Evans, G.W. , Basadur, M. 2007. The impact of training on the formulation of illstructured problems. Omega, 35: 221-236.

Eom, S., \& Kim, E. 2006. A survey of decision support system applications (1995-2001). Journal of the Operational Research Society, 57(11), 1264-1278.

Fentem, A. C., Dumas, A., \& McDonnell, J. 1998. Evolving spatial representations to support innovation and the communication of strategic knowledge. Knowledge-Based Systems, 11(7-8): 417-428. doi:10.1016/S0950-7051(98)00075-6

Finke, R.A., Ward, T.B., \& Smith, S.M. 1992. Creative cognition: Theory, research and application. Cambridge, MA: MIT press.

Forgionne, G. \& Newman, J. 2007. An experiment on the effectiveness of creativity enhancing decisionmaking support systems. Decision Support Systems, 42: 2126-2136.

Gabriel, A., Monticolo, D., Camargo, M., \& Bourgault, M. 2016. Creativity support systems: A systematic mapping study. Thinking Skills and Creativity, 21, 109-122.

Garfield, M. J., Taylor, N. J., Dennis, A. R., \& Satzinger, J. W. 2001. Research report: Modifying paradigms - Individual differences, creativity techniques, and exposure to ideas in group idea generation. Information Systems Research, 12(3): 322-333. doi:10.1287/isre.12.3.322.9710

Gerber, E. M., \& Martin, C. K. 2012. Supporting creativity within web-based self-services. International Journal of Design, 6(1), 85-100.

Gero, J.S. 1996. Creativity, emergence and evolution in design. Knowledge-Based System, 9: 435-448.

Gero, J.S. 2000. Computational models of innovative and creative design processes. Technological Forecasting and Social Change, 64: 183-196. 
Goldenberg, J., Mazursky, D., \& Solomon, S. 1999a. Creative sparks. Science, 285(5433): 1495-1496. doi:10.1126/science.285.5433.1495

Goldenberg, J., Mazursky, D., \& Solomon, S. 1999b. The fundamental templates of quality ads. Marketing Science, 18(3): 333-351. doi:10.1287/mksc.18.3.333

Goldenberg, J., Mazursky, D., \& Solomon, S. 1999c. Toward identifying the inventive templates of new products: A channeled ideation approach. Journal of Marketing Research, 36(2): 200-210. doi: $10.2307 / 3152093$

Gomes, P., Seco, N., Pereira, F. C., Paiva, P., Carreiro, P., Ferreira, J. L., \& Bento, C. 2006. The importance of retrieval in creative design analogies. Knowledge-Based Systems, 19(7): 480-488. doi:10.1016/j.knosys.2006.04.006

Greene, S.L. 2002. Characteristics of applications that support creativity. Communications of ACM, 45: 100-104.

Hedblom, M. M., Kutz, O., \& Neuhaus, F. 2016. Image schemas in computational conceptual blending. Cognitive Systems Research, 39, 42-57.

Helie, S., \& Sun, R. 2010. Incubation, Insight, and Creative Problem Solving: A Unified Theory and a Connectionist Model. Psychological Review, 117(3): 994-1024.

Herring, S.R., Jones, B.R., \& Bailey, B.P. 2009. Idea generation techniques among creative professionals. Proceedings of the 42nd Hawaii International Conference on System Sciences, 1-10.

Hewett, T.T. 2005. Informing the design of computer-based environments to support creativity. International Journal of Human-Computer Studies, 63: 383-409.

Hevner, A. R., March, S. T., Park, J., \& Ram, S. 2004. Design Science in Information Systems Research. MIS Quarterly, 28(1): 75-105.

Hori, K. 1997. Concept space connected to knowledge processing for supporting creative design. Knowledge-Based Systems, 10(1): 29-35. doi:10.1016/S0950-7051(97)00011-7

Howard, T. J., Culley, S., \& Dekoninck, E. A. 2011. Reuse of ideas and concepts for creative stimuli in engineering design. Journal of Engineering Design, 22(8): 565-581.

Hung, E. C. K., \& Choy, C. S. T. 2013. Conceptual Recombination: A method for producing exploratory and transformational creativity in creative works. Knowledge-Based Systems, 53: 1-12. doi:10.1016/j.knosys.2013.07.007

Jansson, D., \& Smith, S. 1991. Design Fixation. Design Studies, 12: 3-11.

Jenkin, T. A., Chan, Y. E., Skillicorn, D. B., \& Rogers, K. W. 2013. Individual Exploration, Sensemaking, and Innovation: A Design for the Discovery of Novel Information. Decision Sciences, 44(6): 10211057.

Kirton, M. 1976. Adaptors and innovators: A description and measure. Journal of Applied Psychology, 61(5): 622-629.

Klein, E. E., \& Dologite, D. G. 2000. The role of computer support tools and gender composition in innovative information system idea generation by small groups. Computers in Human Behavior, 16(2): 111-139. doi:10.1016/S0747-5632(00)00013-3

Kletke, M. G., Mackay, J. M., Barr, S. H., \& Jones, B. 2001. Creativity in the organization: The role of individual creative problem solving and computer support. International Journal of Human Computer Studies, 55(3): 217-237. doi:10.1006/ijhc.2001.0467

Knoll, S. W., \& Horton, G. 2011. Changing the Perspective: Using a Cognitive Model to Improve thinkLets for Ideation. Journal of Management Information Systems, 28(1): 85-114. doi:10.2753/MIS0742-1222280104

Koestler, A. 1964. The act of creation. New York: Penguin Books.

Koh, E. , Kerne, A., \& Hill, R. 2007. Creativity support: Information discovery and exploratory search. Proceedings of $30^{\text {th }}$ Annual International ACM SIGIR Conference on Research and Development in Information Retrieval, SIGIR'07, 895-896.

Kohn, N.W., Paulus, P.B. , \& Korde, R.M. 2011. Conceptual combinations and subsequent creativity. Creativity Research Journal, 23: 203-210. 
Lewis, S., Dontcheva, M., \& Gerber, E. 2011. Affective Computational Priming and Creativity. In Proceedings of the SIGCHI Conference on Human Factors in Computing Systems (pp. 735744). New York, NY, USA: ACM. doi:10.1145/1978942.1979048

Liu, X., Li, Y., Pan, P., \& Li, W. 2011. Research on computer-aided creative design platform based on creativity model. Expert systems with applications, 38(8), 9973-9990.

Lopes, J. S., Álvarez-Napagao, S., \& Vazquez-Salceda, J. 2009. USE: a concept-based recommendation system to support creative search. IEEE/WIC/ACM International Joint Conferences on Web Intelligence and Intelligent Agent Technologies, 3, 17-21.

Lubart, T. 2005. How can computers be partners in the creative process: Classification and commentary on the special issue. International Journal of Human-Computer Studies, 63: 365-369.

MacCrimmon, K.R., \& Wagner, C. 1992. The architecture of an information system for the support of alternative generation. Journal of Management Information Systems, 8: 49-67.

MacCrimmon, K.R., \& Wagner, C. 1994. Stimulating ideas through creativity software. Management Science, 40: 1514-1532.

Malaga, R.A. 2000. The effect of stimulus modes and associative distance in individual creativity support systems. Decision Support Systems, 29: 125-141.

Marakas, G.M. , \& Elam, J. J. 1997. Creativity enhancement in problem solving: Through software or process? Management Science, 43: 83-97.

Massetti, B.1996. An empirical examination of the value of creativity support systems on idea generation. MIS Quarterly, 20: 83-97.

McCaffrey, T., \& Spector, L.2011. How the obscure features hypothesis leads to innovation assistant software. Proceedings of the $2^{\text {nd }}$ International Conference on Computational Creativity, 120122.

Mednick, S.A. 1962. The associative basis of the creative process. Psychological Review, 69:220-232.

Müller, O., Debortoli, S., \& Seidel, S. 2013. MUSE: Implementation of a design theory for systems that support convergent and divergent thinking. 8th International Conference on Design Science at the Intersection of Physical and Virtual Design, 438-445.

Mueller-Wienbergen, F., Mueller, O., Seidel, S., \& Becker, J. 2011. Leaving the beaten tracks in creative work - A design theory for systems that support convergent and divergent thinking. Journal of the Association for Information Systems, 12:714-740.

Mumford, M.D., Baughman, W.A., Threlfall, K.V. , Supinski, E.P., \& Costanza D.P. 1996. Processbased measures of creative problem solving skills: I. Problem construction. Creativity Research Journal, 9: 63-76.

Nagasundaram, M., \& Bostrom, R. P. 1994. The structuring of creative processes using GSS: A framework for research. Journal of Management Information Systems, 10(4): 87-114.

Nijstad, B.A., \& Stroebe, W.2006. How the group affects the mind: A cognitive model of ideation in groups. Personality and Social Psychology Review, 10: 186-213.

Nijstad, B.A., De Dreu, C.K.W., Rietzschel, E.F., \& Baas, M. 2010. The dual pathway to creativity model: Creative ideation as a function of flexibility and persistence. European Review of Social Psychology, 21 (1), 34-77.

Olteţeanu, A. M., \& Falomir, Z. 2016. Object replacement and object composition in a creative cognitive system. Towards a computational solver of the Alternative Uses Test. Cognitive Systems Research, 39, 15-32.

Paivio, A., \& Lambert, W. 1981. Dual coding and bilingual memory. Journal of Verbal Learning and Verbal Behavior, 20: 532-539.

Pereira, F. C., \& Cardoso, A. 2006. Experiments with free concept generation in Divago. KnowledgeBased Systems, 19(7): 459-470. doi:10.1016/j.knosys.2006.04.008

Plucker, J. A., \& Runco, M. A. 1999. Enhancement of creativity. Encyclopedia of creativity, 1, 669-675.

Puccio, G.J., Murdock M., \& Mance, M. 2007. Creative leadership: Skills that drive change. Thousand Oaks, CA: SAGE. 
Puccio, G.J., Wheeler, R.A., \& Cassandro, V.J. 2004. Reactions to creative problem solving: Does cognitive style make a difference. Journal of Creative Behavior, 38(3): 192-216.

Redmond, M.R., Mumford, M.D., \& Teach, R. 1993. Putting creativity to work: Effects of leader behavior on subordinate creativity. Organizational behavior and Human Decision Process, 55: 120-151.

Rhodes, M. 1961. An analysis of creativity. Phi Delta Kappan, 42: 305-310.

Riley, P., Alm, N., \& Newell, A. 2009. An interactive tool to promote musical creativity in people with dementia. Computers in Human Behavior, 25(3), 599-608.

Runco, M. A. 2007. Creativity Theories and Themes: Research, Development, and Practice. Burlinton, MA: Elsevier.

Santanen, E.L., Briggs, R.O., \& de Vreede, G. 2004. Causal relationships in creative problem solving: Comparing facilitation interventions for ideation. Journal of Management Information Systems, 20: 167-197.

Sedivy, J., \& Johnson, H. 2000. Multimodal tool support for creative tasks in the visual arts. KnowledgeBased Systems, 13(7-8): 441-450. doi:10.1016/S0950-7051(00)00064-2Shneiderman, B. 2002. Creativity support tools. Communications of the ACM, 45: 116-120.

Seo, Y. W., Chae, S. W., \& Lee, K. C. 2014. The impact of absorptive capacity, exploration, and exploitation on individual creativity: Moderating effect of subjective well-being. Computers in Human Behavior, 42: 68-82. doi:10.1016/j.chb.2014.03.031

Setchi, R., \& Bouchard, C. 2010. In search of design inspiration: a semantic-based approach. Journal of Computing and Information Science in Engineering, 10(3), 031006.

Shai, O., Reich, Y., \& Rubin, D. 2009. Creative conceptual design: extending the scope by infused design. Computer-aided design, 41(3), 117-135.

Shneiderman, B., Fischer, G., Czerwinski, M., Resnick, M., Myers, B., Candy, L., \& Terry, M. 2006. Creativity Support Tools: Report From a U.S. National Science Foundation Sponsored Workshop. International Journal of Human-Computer Interaction, 20: 61-77.

Simonton, D. K. 1989. The chance-configuration theory of scientific creativity. In B. Gholson, W. R. Shadish, Jr., R. A. Neimeyer, \& A. C. Houts (Eds.), The psychology of science: Contributions to metascience: 170-213. Cambridge, England, Cambridge University Press.

Sinha, A. P., \& May, J. H. 1996. Providing Design Assistance: A Case-Based Approach. Information Systems Research, 7(3): 363-387. doi:10.1287/isre.7.3.363

Smith, G.F. 1998. Idea generation techniques: A formulary of active ingredients. Journal of Creative Behavior, 32: 107-134.

Sternberg, R.J. 1988. The nature of creativity: Contemporary psychological perspectives. New York: Cambridge University Press.

Sugimoto, M., Hori, K., \& Ohsuga, S. 1994. Method to assist the building and expression of subjective concepts and its application to design problems. Knowledge-Based Systems, 7: 233-238.

Sugimoto, M., Hori, K., \& Ohsuga, S. 1996. A system to visualize different viewpoints for supporting researchers' creativity. Knowledge-Based Systems, 9(6): 369-376. doi:10.1016/S09507051(96)01048-9

Tennyson, R. D., \& Breuer, K. 2002. Improving problem solving and creativity through use of complexdynamic simulations. Computers in Human Behavior, 18(6): 650-668. doi:10.1016/S07475632(02)00022-5

Treffinger, D. J. 1995. Creative problem solving: Overview and educational implications. Educational Psychology Review, 7(3), 301-312.

VanGundy, A. B. 1988. Techniques of Structured Problem Solving. New York, VanNostrand Reinhold.

Vattam, S., Wiltgen, B., Helms, M., Goel, A. K., \& Yen, J. 2010. DANE: Fostering Creativity in and through Biologically Inspired Design. Design Creativity, 115-122.

Veale, T. 2006. An analogy-oriented type hierarchy for linguistic creativity. Knowledge-Based Systems, 19(7): 471-479. doi:10.1016/j.knosys.2006.04.007 
Viriyayudhakorn, K., \& Kunifuji, S. 2013. Automatic Topic Identification for Idea Summarization in Idea Visualization Programs. IEICE Transactions on Information and Systems, E96D(1): 64-72.

Viriyayudhakorn, K., Kunifuji, S., \& Ogawa, M. 2011. A comparison of four association engines in divergent thinking support systems on Wikipedia. In Knowledge, Information, and Creativity Support Systems: 226-237. Heidelberg: Springer Berlin.

Voigt, D. W. I. M., Bergener, K., \& Becker, J. 2013. Comprehensive Support for Creativity-Intensive Processes. Business \& Information Systems Engineering, 5(4), 227-242.

Voigt, M., Niehaves, B., \& Becker, J. 2012. Towards a unified design theory for creativity support systems. In Design Science Research in Information Systems. Advances in Theory and Practice: 152-173. Heidelberg: Springer Berlin.

Volkema, R.J. 1983. Problem formulation in planning and design. Management Science, 29: 639-652.

Wallas, G.1926. The art of thought. New York: Harcourt Brace.

Wang, H., \& Ohsawa, Y. 2013. Idea discovery: A scenario-based systematic approach for decision making in market innovation. Expert Systems with Applications, 40(2), 429-438.

Wang, H.-C., Cosley, D., \& Fussell, S. R. 2010. Idea Expander: Supporting Group Brainstorming with Conversationally Triggered Visual Thinking Stimuli. Proceedings of the 2010 ACM Conference on Computer Supported Cooperative Work, 103-106.

Wang, K. 2014. Factors influencing the adoption and effective use of creativity techniques in business settings: An exploratory study. Engineering Management Journal, 26(4): 29-37.

Wang, K., Nickerson, J.V., Sakamoto, Y. 2013. Crowdsourced idea generation: The effect of exposure to an original idea. The 19th Americas Conference on Information Systems.

Wiggins, G. A. 2006. A preliminary framework for description, analysis and comparison of creative systems. Knowledge-Based Systems, 19(7): 449-458. doi:10.1016/j.knosys.2006.04.009

Wilson, J. O., Rosen, D., Nelson, B. A., \& Yen, J. 2010. The effects of biological examples in idea generation. Design Studies, 31(2): 169-186. doi:10.1016/j.destud.2009.10.003

Yamamoto, Y., Nakakoji, K. 2005. Interaction design of tools for fostering creativity in the early stages of information design. International Journal of Human-Computer Studies, 63:513-535.

Yilmaz, S., \& Seifert, C. M. 2011. Creativity through design heuristics: A case study of expert product design. Design Studies, 32(4): 384-415. doi:10.1016/j.destud.2011.01.003

Young, L. F. 1987. The metaphor machine: A database method for creativity support. Decision Support Systems, 3(4): 309-317.

Zanni-Merk, C., Cavallucci, D., \& Rousselot, F. 2009. An ontological basis for computer aided innovation. Computers in Industry, 60(8), 563-574. 